\title{
The Role of Tourism Village to Increase Local Community Income
}

\author{
${ }^{1}$ Dino Leonandri, ${ }^{2}$ Maskarto Lucky Nara Rosmadi \\ ${ }^{1}$ Departement of Management, Trisakti Tourism Institute (STP) of Jakarta, Indonesia \\ ${ }^{2}$ Institute of Economic Science (STIE) Kridatama Bandung, Indonesia \\ maskartolucky@gmail.com
}

\begin{abstract}
This study aimed at finding and analyzing the role of tourism villages in increasing local people's income. The problem faced is lack of synergy between the local community, local government, and other stakeholders. The method used is a qualitative method with a descriptive explorative approach. From the results of the study, it was found that tourism villages could open employment opportunities, elevate regional culture, and develop economic potential and welfare of the local community who prioritized populist economy based on local wisdom. From this study it can be concluded that the role of village tourism has a significant impact on local communities, especially can increase family income.
\end{abstract}

Keywords: tourism village; employment; community economy

\section{Introduction}

Today's tourism is a major commodity for the Indonesian people to obtain foreign exchange and as a way to increase economic growth and introduce culture both in urban and rural areas [1]. To be a tourist attraction, of course the government must issue policies relating to tourism so that the implementation can truly be felt by the community [2] - [5]. The tourists usually choose a lot of tourist destinations related to nature by promoting culture and local wisdom and can entertain them while educating them such as hiking, trekking, cultural tourism and tourist villages [6] - [8].

Tourism village is a new destination developed by the government in an effort to equalize development and improve community welfare. In addition to that, the construction of tourist villages is also to preserve the environment and to elevate the local potential based on local wisdom [9]. Tourist village destinations are built and opened in addition to increasing the income of local communities and local governments as well as providing a new atmosphere for local and foreign tourists [10], [11].

Palalangon is a tourism village located in Pasirjambu District, Bandung Regency, which has beautiful nature which is supported by Gambung tea plantations. This tourist village offers a new atmosphere and can meet the needs of tourists visiting the area [12]. Therefore the role of researchers through their studies is expected to be able to provide input and understanding for the community and local government to provide services needed by tourists to be able to visit the area [13] - [16].

From the description above, it can be conveyed, the extent of the role of tourism villages in increasing the income of local communities. The purpose of this study is to find out and analyze the role of tourism villages in increasing local people's income.

\subsection{Tourism Village}

\section{Review of Literature}

The Indonesian government's program in an effort to equate development, create jobs and reduce poverty is through empowering regional potential by promoting local wisdom. One government program is to develop potential in the tourism sector which is a service 
sector that can rapidly develop and can generate foreign exchange for the country [17]. The development of modern tourist destinations needs to be carefully planned including providing supporting facilities both by the local government, the surrounding community and other stakeholders so that they can become a source of power and attractiveness which in turn is in great demand by tourists [18] - [21].

Tourism businesses must also be able to evaluate the strengths and weaknesses of the construction of tourist villages so that competitiveness can be known from the regions they developed for a long period of time in the tourism market [22], [23]. From research conducted by Bashar and Ajloni [ 24], Chiu et al. [25], Rajaratnam and Nair [26], Chang and Tsai [27], and Akhoondnejad [28] it can be concluded, that the presence of tourist villages for tourists has different views from the motivation to develop tourist villages, the image of tourist villages, impact on tourists, and culture with the presence of tourist villages with cultural integration as the main factors that influence tourism attractiveness.

\subsection{Employment}

The world of tourism is a non-oil foreign exchange producer that can be obtained by the state from the presence of tourists, especially from foreign countries. 29. The development of a region into a new destination in the form of tourist villages can increase the income of local people because of the absorption of many workers. This certainly must be maintained by the local community by providing the best service to tourists [30], [31]. In addition to providing a positive impact in the form of employment, the local community together with the local government must be able to maintain negative impacts, especially related to environmental and cultural preservation in the area [32].

Research conducted by Manoj [29], Noori \& Zand [30], Singh et al [33], Balan \& Burghelea [34] it can be concluded that the presence of tourist destinations in a region has a positive impact on development especially related to the absorption of employment, development infrastructure, community income, and the development of local culture.

\subsection{The Economy of society}

The presence of tourism destinations in an area besides aiming for equitable development, raising regional culture also to reduce poverty and improve the economy for the local community. Support for infrastructure and other facilities can accelerate economic improvement [35], [36].

The presence of tourist villages in Pasirjambu District, Bandung Regency can also improve the economy of the community, reduce unemployment, and prosper the local community [30], [37]. The results of research conducted by Zaei \& Zaei [37], Tanrivermi \& Sanli [38], Rathore [39] It can be concluded that the development of tourist destinations in an area has a positive impact on improving the economy of the local community.

\section{Research Methods}

The study was conducted in Palalangonyang Tourism Village in Pasirjambu District, Bandung Regency. The research method used is a qualitative method with descriptive explorative type. Primary data was obtained from interviews with key informants, informants and direct observations by researchers at the research location, while secondary data was 
obtained from literary sources, Bandung Regency Tourism Office, and literature sources. This research is classified into cross-section research, because it takes one part of the symptoms at one time. This research is carried out in a certain time and is only done in one time only and will not do other research at different times to be compared.

\section{Results and Discussion}

From the research conducted in Pasirjambu District, Bandung Regency, the following data were obtained:
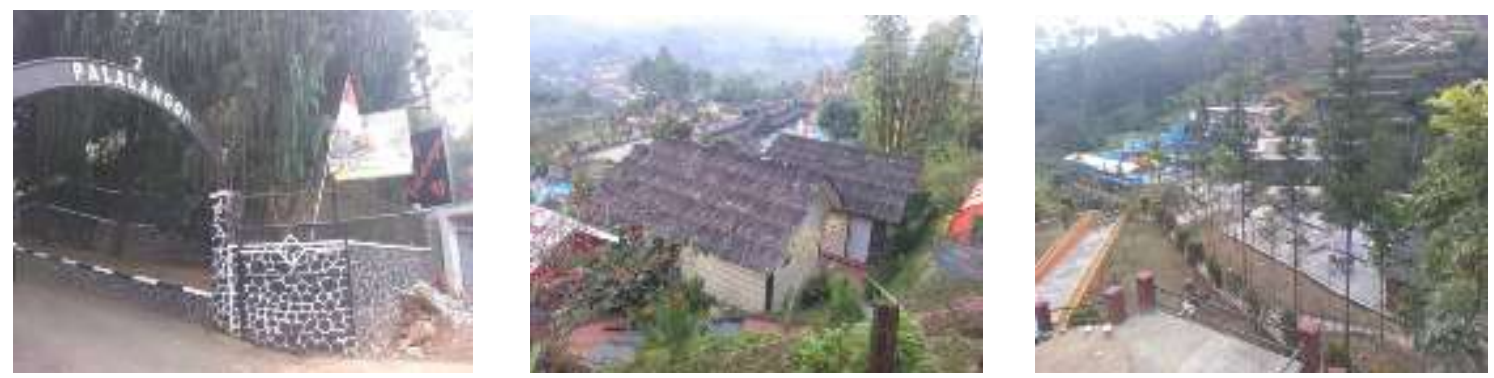

Figure 1. Palalangon Tourism Village, Bandung Regency

From figure 1. Above can be explained that Palalangon tourism village has good potential to be developed. Although this tourist village is relatively new, but the tourist destinations are not inferior to the potential of other tourist objects in Bandung Regency such as White Crater, Ciwalini Hot Springs, and Situ Patengan. Adequate infrastructure is a support for the interest of tourists to visit Bandung Regency.

The supporting destinations of Palalangon tourist village can be seen in the following picture:
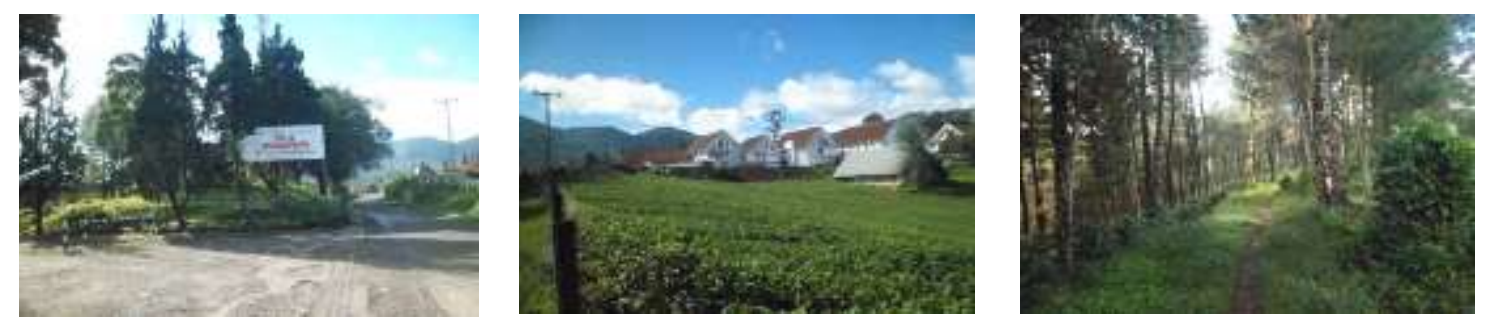

Figure 2. Gambung Tea Plantation

From figure 2 above, it can be explained, that the Gambung tea plantation can be an attraction for tourists to come to visit the tourist village of Palalangon. Beautiful atmosphere and equipped with rustic lodging.

From the two images above, it can be explained that the existence of a tourist village in Pasirjambu District in addition to traveling can also provide additional income for the surrounding community. This is supported by the data listed in the following table: 
Table 1.1 Tourist Visits to Bandung Regency in 2011-2013

\begin{tabular}{|c|l|c|c|c|}
\hline No & \multicolumn{1}{|c|}{ Indicator } & $\mathbf{2 0 1 1}$ & $\mathbf{2 0 1 2}$ & $\mathbf{2 0 1 3}$ \\
\hline 1 & Number of Tourists & 1.124 .142 & 1.645 .569 & 1.234 .555 \\
\hline 2 & Number of Tourist Destinations & 40 & 45 & 50 \\
\hline 3 & $\begin{array}{l}\text { Number of Tourism Work Partners } \\
\text { (People) }\end{array}$ & 1.124 & 1.224 & 1.312 \\
\hline
\end{tabular}

Source: 2013 Regency Bandung Dispopar

From the table above, it can be seen that the number of tourist visits to Bandung Regency has increased. Only in 2013 did tourist visits decrease due to the lack of good infrastructure to get to tourist attractions. but after the infrastructure was fixed the number of tourists experienced a significant increase. Bandung Regency Tourism and Culture Office targets the number of tourist visits for 2017 to be 2.1 million visitors, but it exceeds the target of 2.6 million visitors.

From the description above, it supports the opinion of Mair \& Jago [10] and Rittichainuwat et al. [11] which states that the existence of tourist villages has an impact on many aspects of life in an area, including increasing local people's income, opening new employment opportunities, local culture is increasingly famous, and the region's economy is more advanced. This opinion is supported by the results of a study conducted by Zaei \& Zaei [37], Tanrivermi \& Sanli [38], Rathore [39] that tourism destinations if managed well have a positive impact on improving the economy of the community.

\section{Conclusion}

From the results of the research conducted, it can be concluded that the existence of tourist villages has a positive impact on local communities. Development of tourist villages also opens new employment opportunities, raises the culture and potential that exist in the area and can accelerate the distribution of development which in turn can increase the income and welfare of the local community. The constraints faced by the regions that are used as tourist villages are the lack of synergy between stakeholders and the local community, especially related to the provision of infrastructure, the development of quality human resources, and capital.

\section{References}

[1] Stephen L.J. Smith, The Measurement of Global Tourism: Old Debates, New Consensus, and Continuing Challenges, A. Companion to Tourism ed., Alan A. Lew, C. Michael Hall, and Allan M. Williams, Eds. Oxford, USA: Blackwell Publishing Ltd., 2004.

[2] Colin Michael Hall, Tourism and Politics: Policy, Power and Place. Chichester: John Wiley \& Sons, 1994.

[3] Colin Michael Hall and John Michael Jenkins, Tourism and Public Policy. New York: Routledge, 1996. 
[4] M. Dolors Garcia, Ramon Gemma Canoves, and Nuria Valdovinos, "Farm Tourism, Gender and The Environment in Spain," Annals of Tourism Research, vol. 22, no. 2, pp. 267-282, 1995.

[5] James Elliot, Tourism: Politics and Public Sector Management. New York: Routledge, 1997.

[6] Olga Iakovidou and Caroline Turner, "The Female Gender in Greek Agrotourism," Annals of Tourism Research, vol. 22, no. 2, pp. 481-484, 1995.

[7] Martin Oppermann, "Rural Tourism in Southern Germany," Annals of Tourism, vol. 23, no. 1, pp. 86-102, 1996.

[8] Surjya Chutia, "Prospects and Problems of Tourism Industry in Assam," International Journal of Innovative Research in Science, Engineering and Technology, vol. 4, no. 2, pp. 633-638, Februari 2015.

[9] Steven Pike and Chris Ryan, "Destination Positioning Analysis through a Comparison of Cognitive, Affective and Conative Perceptions," Journal of Travel Research, vol. 42, no. 4, pp. 333-342, 2004.

[10] Judith Mair and Leo Jago, "The Development of a Conceptual Model of Greening in the Business Tourism Sector," Journal of Sustainable Tourism, vol. 18, no. 1, pp. 77-94, 2010.

[11] Bongkosh Ngamsom Rittichainuwat, Hailin Qu, and Chollada Mongkhonvanit, "Understanding the Motivation of Travelers on Repeat Visits to Thailand," Journal of Vacation Marketing, vol. 14, no. 1, pp. 1-21, January 2008.

[12] Duk Byeong Park and Yoo Shik Yoon, "Segmentation by Motivation in Rural Tourism: A Study Korean Case Study," Tourism Management, vol. 30, no. 1, pp. 99-108, February 2009.

[13] Antonia Correia, Patricia Oom do Valle, and Claudia Moco, "Why People Travel to Exotic Places," Tourism and Hospitality Research, vol. 1, no. 1, pp. 45-61, 2007.

[14] Chu Yin Chiang and Giri Jogaratnam, "Why Women Travel Solo for Purposes of Leisure," Journal of Vacation Marketing, vol. 12, no. 1, pp. 59-70, January 2006.

[15] Nam Su Kim and Laurence Chalip, "Why Travel to the FIFA World Cup? Effects of Motives, Background, Interest, and Constraints," Tourism Management, vol. 25, no. 6, pp. 695-707, December 2004.

[16] Alison Caffyn and Guy Jobbins, "Governance Capacity and Stakeholder Interactions in the Development and Management of Coastal Tourism: Examples from Morocco and Tunisia," Journal of Sustainable Tourism, vol. 11, no. 2-3, pp. 224-245, 2003.

[17] Wanninayake M. Semasinghe, "International Tourism of Post-War Srilanka Development, Challenge and Opportunities," International Journal of Economics, Commerce and Management, vol. IV, no. 6, pp. 1-18, June 2016.

[18] B.J.R. Ritchie and G.I. Crouch, "The competitive destination: A sustainability Perspective," Tourism Management, vol. 21, no. 2, pp. 1-7, January 2000.

[19] Luiz Gustavo Medeiros Barbosa, Carlyle Tadeu Falcao de Oliveira, and Cristiane Rezende, "Competitiveness of Tourist Destinations: the Study of 65 Key Destinations for the Development of Regional Tourism," Revista de Administracao Publica, vol. 44, no. 5, pp. 1067-1095, 2010.

[20] Maria Francesca Cracolici and Peter Nijkamp, "The attractiveness and competitiveness of tourist destinations: A study of Southern Italian Regions," Tourism Management, vol. 30, no. 3, pp. 336344, June 2009.

[21] Douglas G. Pearce and Heike A. Schanzel, "Destinations: Tourists' Perspectives from New Zealand," International Journal of Tourism Research, vol. 17, no. 1, pp. 4-12, January 2015.

[22] Perunjodi Naidoo, Jeynakshi Ladsawut, and Prabha Ramseook Munhurrun, "Tourist Satisfaction with Mauritius as a Holiday Destination," Global Journal of Business Research, vol. 4, no. 2, pp. 
113-123, 2010.

[23] Meltem Caber, Tahir Albayrak, and Kurt Matzler, "Classifi Cation of the Destination Attributes in the Content of Competitiveness (by revised importance-performance analysis)," Journal of Vacation Marketing, vol. 18, no. 1, pp. 43-56, January 2012.

[24] Bashar and Abdallah Ali Al Ajloni, "Motivating Foreign Tourist to Visit The Rural Site in Jordan, Village of Petra," Australian Journal of Business and Management Research, vol. 2, no. 5, pp. 1-7, Agustus 2012.

[25] Weisheng Chiu, Shiheng Zeng, Philip Shao, and Tung Cheng, "The Influence of Destination Image and Tourist Satisfaction on Tourist Loyalty: a Case Study of Chinese Tourists in Korea," International Journal of Culture, Tourism and Hospitality Research, vol. 10, no. 2, pp. 223-234, January 2016.

[26] Sushila Devi Rajaratman, Vicneswaran Nair, Saeed Pahlevan Sharif, and Uma Thevi Munikrishnan, "Destination Quality and Tourists' Behavioural Intentions: Rural Tourist Destinations in Malaysia," Worldwide Hospitality and Tourism Themes, vol. 7, no. 5, pp. 463-472, 2015.

[27] Feng Hsiang Chang and Chih Yung Tsai, "Influences of The Cultural Implications and Tourism Attractiveness of Festival Tourism on Tourist," Journal of Business and Management Studies, vol. 2, no. 1, pp. 1-10, May 2016.

[28] Arman Akhoondnejad, "Tourist Loyalty to a Local Culture Event: the Case of Turkmen Handicrafts Festival," Journal of Tourism Management, vol. 52, pp. 468-477, February 2016.

[29] P.K. Manoj, "Employment Generation from Rural Tourism: a Field Study of the Local Community at Kumbalang in Kerala," International Journal of Applied Services Marketing Perspectives, vol. 4, no. 4, pp. 1880-1888, December 2015.

[30] Kamran Noori and Farhad Zand, "The Role of Rural Tourism in Rural Sustainable Development According to the SWOT Method (Case Study: Kermanshah Province villages)," International Research Journal of Applied and Business Sciences, vol. 4, no. 9, pp. 2620-2625, 2013.

[31] Yazdi M. Papoli and M. Sagael, Tourism, essence and implications. Teheran, Iran: Samt Press, 2006.

[32] Ferhan Gezici, "Components of Sustainability: Two Cases from Turkey," Annals of Tourism Research, vol. 3, no. 2, pp. 442-455, April 2006.

[33] Kuldeep Singh, Arnab Gantait, Goldi Puri, and Anjaneya G. Swamy, Rural Tourism: Need, Scope and Challenges in Indian Context. Hospitality and Tourism: Challenges, Innovation, Practices and Product Development. New Delhi, India: Adhyayan Publisher and Distributors, 2016.

[34] Mariana Balan and Cristina Burghelea, "Rural tourism and its implication in the development of the Fundata Village," Science Direct, vol. 188, pp. 276-281, 2015.

[35] Tiago Neves Sequeira and Paulo Macas Nunes, "Does Tourism Influence Economic Growth? A dynamic panel data approach," Journal Applied Economics, vol. 40, no. 18, pp. 2431-2441, 2008.

[36] Wiston Adrian Risso, Juan Gabriel Brida, and Annarita Bonapace, "The Contribution of Tourism to Economic Growth: an Empirical Analysis for the case of Chile," Monza, Italy, November 2008.

[37] Mansour Esmaeil Zaei and Mahin Esmaeil Zaei, "The Impacts of Tourism Industry on Host Community," European Journal of Tourism Hospitality and Research, vol. 1, no. 2, pp. 12-21, September 2013.

[38] H. Tanrivermi and H. Sanli, "A Research on the Impacts of Tourism on Rural Household Income and Farm Enterprises: The Case of the $\mathrm{Nev}_{s}$ sehir Province of Turkey," Journal of Agriculture and Rural Development in the Tropics and Subtropics, vol. 108, no. 2, pp. 169-189, 2007.

[39] Nisha Rathore, "Rural Tourism Impact, Challenges and Opportunities, ZENITH International Journal of Business Economics \& Management Research, vol. 2, no. 2, pp. 252-260, February 2012. 